\title{
ÜBER EINIGE NAMEN
}

vON

\section{BERGEN, THÄLERN, WEILERN,}

\author{
WEIDEN UND HÜTTEN
}

IN DER UMGEBUNG VON

\section{MADONNA DI CAMPIGLIO \\ VON}

DR. HEINRICH SABERSKY.

MIT EINER KARTE.

STRASSBURG

VERLAG VON KARL J. TRUUBNER.

I899. 
